\title{
Antioxidant activity of camel milk casein before and after in vitro simulated enzymatic digestion
}

\begin{abstract}
doi: $10.15567 /$ mljekarstvo.2014.0408
Zeineb Jrad ${ }^{1,2 *}$, Jean-Michel Girardet ${ }^{3,4}$, Isabelle Adt ${ }^{5}$, Nadia Oulahal ${ }^{5}$, Pascal Degraeve ${ }^{5}$, Touhami Khorchani ${ }^{1}$, Halima El Hatmi ${ }^{1,2}$

${ }^{1}$ Laboratoire d'Elevage et Faune Sauvage, Institut des Régions Arides de Médenine, Tunisie

${ }^{2}$ Département agro-alimentaire, Institut Supérieur de Biologie Appliquée de Médenine, Université de Gabes, Tunisie ${ }^{3}$ Université de Lorraine, URAFPA (Unité de Recherche Animal et Fonctionnalités des Produits Animaux), Vandœuvre-lès-Nancy, F-54506, France

${ }^{4}$ INRA, URAFPA Unité Sous Contrat 340, Vandœuvre-lès-Nancy, F-54506, France

${ }^{5}$ Université de Lyon, Université Lyon 1, BioDyMIA* (Bioingénierie et Dynamique Microbienne aux Interfaces Alimentaires) Equipe Mixte d'Accueil n 3733 Université Lyon 1 - ISARA Lyon, Technopole

Alimentec - rue Henri de Boissieu, Bourg en Bresse, F-01000, France

Received - Prispjelo: 11.01.2014.

Accepted - Prihvaćeno: 12.09.2014.

Abstract

The effect of a successive in vitro hydrolysis by pepsin and pancreatin on the free radical scavenging activity of camel milk casein was investigated in order to assess the effect of gastro-intestinal digestion. Hydrolysis of camel casein was controlled by reversed-phase high performance liquid chromatography. Anti-oxidant activity was measured by the 2,2'-azino-bis-(3-ethylbensothiazoline-6sulfonic acid) (ABTS) method. The Trolox equivalent antioxidant capacity (TEAC) values of camel casein and its hydrolysate were $1.6 \pm 0.12 \mu \mathrm{mol} \mathrm{TE} / \mathrm{mg}$ protein and $0.25 \mu \mathrm{mol} \mathrm{TE} / \mu \mathrm{mol}$ eq. $\mathrm{NH}_{2}$, respectively. After digestion, the scavenging activity of the casein peptides was more efficient than those reported in the literature regarding digestive hydrolysates of camel milk, colostrum and whey proteins.
\end{abstract}

Key words: camel casein, protein enzymatic digestion, radical scavenging activity, antioxidant

\section{Introduction}

Oxidation is a vital process in all living organisms even though its side effects is the production of free radicals (Ren et al., 2008). The action mechanism of oxidation is related to the inactivation of reactive oxygen species (ROS) by scavenging of free radicals, chelation of pro-oxidative transition metals and reduction of hydroperoxides (Zhou et al., 2012). It is well documented that free radical formation is a major factor involved in the progression of many human diseases, such as heart diseases, stroke, atherosclerosis and cancer, which have been considered as the leading causes of human death (Dávalos et al., 2004).
Butylatedhydroxyanisol (BHA), butylatedhydroxutoluene (BHT) and propyl gallate are synthetic antioxidants used in foods to retard lipid oxidation (Saiga et al., 2003). However, their use is associated with possible health risks (Sakanaka et al., 2004). For this reason, interest in finding natural antioxidants representing an alternative to synthetic ones is high. So, the possible use of many non-enzymatic antioxidants present in fruits and vegetables (polyphenols, flavonoids, iso-flavanones, vitamins A, B, C, E and tocopherols) was well investigated (Kaur and Kapoor, 2001). In the last decade, the production of peptides having antioxidant properties by enzymatic hydrolysis of proteins from animal 
sources has been extensively reported in several studies. Bovine milk is considered as an interesting source of proteins able to generate by enzymatic hydrolysis or during microbial fermentation peptides displaying radical scavenging activity (Pihlanto, 2006).

Camel milk is the most common product in arid regions. The beneficial effects of camel milk, which include the prevention of diseases and conditions such as gastroenteritis, tuberculosis, diabetes and hypertension, have been demonstrated experimentally (Quan et al., 2008 ; Sboui et al., 2010). Therefore, improving the therapeutic value of camel milk has received great attention. Caseins constitutes $75-80 \%$ of proteins of camel milk. Camel casein is very susceptible to proteolysis and able to generate peptides with various biological activities (Salami et al., 2008). Once ingested, one of the conditions for their action on health of the consumers is that the biological activity of these proteins is not impaired by the successive actions of digestive proteolytic enzymes in stomach and in intestine.

The aim of the present work was to assess the effect of an in vitro enzymatic digestion procedure mimicking human gastro-intestinal digestion, on the ABTS radical cation scavenging activity of camel caseins.

\section{Materials and methods}

\section{Materials}

Camel milk was provided from the experimental herd of the Arid Land Institute, Livestock and Wildlife Laboratory (Medenine, Tunisia). Pepsin (from porcine stomach mucosa, EC 3.24.3.1, specific activity of 3260 units $/ \mathrm{mg}$ ) and pancreatin (from bovine pancreas, activity equivalent to $8 \times$ U.S.P. specifications according to the supplier Sigma-Aldrich, EC 232-468-9) were purchased from Sigma-Aldrich (St. Louis, MO, USA). Other chemicals required for the assays including O-phtaldialdehyde (OPA); 6-hydroxy-2,5,7,8-tetramethylchroman-2-carboxylic acid (Trolox), gallic acid; 2,2'-azinobis (3-ethylbenzthiazoline-6-sulfonic acid) (ABTS) were obtained from Sigma-Aldrich. All solutions prepared with double distilled water were kept at $4{ }^{\circ} \mathrm{C}$ until use.

\section{Casein preparation}

Casein were prepared as follows: skimmed camel milk $\mathrm{pH}$ was adjusted to 4.2 by the addition of 1
$\mathrm{M} \mathrm{HCl}$. The mixture was allowed to stand for 30 min at $30^{\circ} \mathrm{C}$ and then centrifuged $(5000 \times \mathrm{g}, 30 \mathrm{~min}$, $20{ }^{\circ} \mathrm{C}$ ). The casein pellet was separated from the whey supernatant, re-suspended and then, washed with distilled water to remove any whey residue. This last operation was repeated twice. Finally, the caseins were obtained by centrifugation at $1500 \times \mathrm{g}$ for $20 \mathrm{~min}$ at $20{ }^{\circ} \mathrm{C}$ and then dissolved with $1 \mathrm{M}$ $\mathrm{NaOH}$. In order to remove salts, the caseins were dialyzed (cut-off of dialysis membrane: 100-500 Da, SpectraPor, Spectrum Labs Inc., Rancho Dominguez, CA, USA) against Milli-Q water (Millipore, Bedford, MA, USA) at $4{ }^{\circ} \mathrm{C}$ for $48 \mathrm{~h}$ and freeze-dried.

\section{Casein hydrolysis}

Hydrolysis of camel milk casein was performed according to the in vitro enzymatic digestion conditions described by Parrot et al. (2003). First, to mimick gastric emptying, digestion was started by adjusting the $\mathrm{pH}$ value of camel milk casein $(\mathrm{CN})$ solution $(20 \mathrm{mg} / \mathrm{mL})$ to $\mathrm{pH}=2.0$ with $1 \mathrm{M} \mathrm{HCl}$. Then, a $1 \mathrm{~g} / \mathrm{L}$ pepsin solution in $0.01 \mathrm{M} \mathrm{HCl}$ was added to caseins in order to obtain a final enzymesubstrate ratio (E:S) of 1:200 (w:w). Camel casein was hydrolyzed by pepsin for $30 \mathrm{~min}$ at $37^{\circ} \mathrm{C}$ in a shaking water bath (160 movements per min). Thereafter, as in human duodenum, peptic digestion products were digested by pancreatin at a slightly basic $\mathrm{pH}$. After the $\mathrm{pH}$ of peptic digestion products was adjusted to 7.5 , a $2 \mathrm{~g} / \mathrm{L}$ pancreatin solution in Milli-Q water was added in order to obtain a final 1:400 (w:w) E:S ratio. The pancreatic hydrolysis of the peptic breakdown products was carried out for $4 \mathrm{~h}$ at $37^{\circ} \mathrm{C}$. The enzymatic hydrolysis was stopped by heating the reaction volume at $85^{\circ} \mathrm{C}$ for $5 \mathrm{~min}$.

\section{Ultrafiltration}

Samples of casein hydrolysates $(\mathrm{CNH})$ were then subjected to an ultrafiltration step. For this reason, a stirred ultrafiltration cell using membrane (76 $\mathrm{mm}$ of diameter) with molecular cut off sizes of $10 \mathrm{kDa}$ (Amicon, Cells Millipore, Saint-Quentin en Yvelines, France) was used. The pressure applied was 2.6 $10^{5} \mathrm{~Pa}$.The permeate was collected, demineralized by dialysis (100-500 Da c.o., SpectraPor, Spectrum labs inc, U.S.A) against 200 volumes of Milli-Q water during $48 \mathrm{~h}$, lyophilized and kept at $-20{ }^{\circ} \mathrm{C}$ until analysis. 


\section{Reversed-Phase High-performance}

Liquid Chromatography (RP-HPLC)

A volume of $50 \mu \mathrm{L}$ containing $5 \mathrm{mg}$ of lyophilized $\mathrm{CN}$ or $\mathrm{CN}-\mathrm{H}$ was loaded onto a Lichrospher $\mathrm{C}_{18}$ analytical column $(150 \times 2 \mathrm{~mm}, 5-\mu \mathrm{m}$ particle size, 10-nm porosity; Cluzeau, Sainte-Foy-La-Grande, France) connected to an Alliance HPLC unit 2690 (Waters Corp., Milford, MA, USA) equipped with a photodiode array detector DAD 996 (Waters). Peptides were then eluted for $90 \mathrm{~min}$ by a linear gradient from 5 to $50 \%$ of acetonitrile in water and in the presence of $0.1 \%$ trifluoroacetic acid. The flow rate was $0.25 \mathrm{~mL} \mathrm{~min}^{-1}$, detection was carried out at $215 \mathrm{~nm}$, and the separation was analysed with the Millennium 32 version 3.05.01 software (Waters).

\section{O-phthaldialdehyde (OPA) and Bradford assays}

The peptide concentration was measured at $340 \mathrm{~nm}$ using a $\mathrm{MRX}^{\circledR}$ microplate reader (Thermolabsystems, Chantilly, VA, USA) by the OPA micromethod adapted for small volumes from that of Frister et al.(1988). The calibration curve was established with leucine and the concentration was expressed in $\mu$ moL equivalent (eq.) $\mathrm{NH}_{2}$.

The protein concentration was determined in triplicate by the Bradford method using bovine serum albumin (BSA) as protein standard and expressed as mg/L eq. BSA (Bradford, 1976).

\section{Determination of casein hydrolysis degree}

The degree of hydrolysis was calculated as described by Spellman et al. (2003):

$$
\mathrm{DH}(\%)=(\mathrm{n} / \mathrm{p}) \times 100
$$

Where $\mathrm{n}$ is the average number of peptide bonds hydrolyzed, $\mathrm{p}$ the total peptide bonds per protein molecule.

Where :

$$
\mathrm{n}=\Delta \mathrm{A}_{340 \mathrm{~nm}} \mathrm{Md} / \varepsilon \mathrm{c}
$$

$\Delta \mathrm{A}_{340 \mathrm{~nm}}=$ the absorbance at $340 \mathrm{~nm}$ difference between the hydrolysate and the initial sample,

$\mathrm{M}$ - the total molecular weight of proteins $(\mathrm{Da})$,

$\mathrm{d}$ - the dilution factor,

$\varepsilon$ - the molar extinction coefficient at $340 \mathrm{~nm}(6000$

$\mathrm{M}^{-1} \mathrm{~cm}^{-1}$ ), and

$\mathrm{c}$ - the protein concentration $(\mathrm{g} / \mathrm{L})$.
As $\mathrm{CN}$ contained a heterogeneous mixture of many different proteins, the average number of peptide bonds per mole of $\mathrm{CN}$ and theaverage molecular mass of the proteins in CN were estimated as follows. Values were calculated taking the approximate protein content of $\mathrm{CN}$ in camel milk to be $31.5 \%$ of $\alpha_{\mathrm{s}}-\mathrm{CN} ; 65 \%$ of $\beta-\mathrm{CN}$ and $3.5 \%$ of $\kappa-\mathrm{CN}$ according to Kappeler (1998). Taking these values into account, the average molecular weight of the proteins in CN was calculated to be 30916 Da (M), with an average of 204 peptide bonds per protein molecule (p) according to Spellman et al. (2003).

\section{Determination of radical scavenging activity}

The free radical scavenging activity of camel whole casein $(\mathrm{CN})$ and their hydrolysates $(\mathrm{CNH})$ were analyzed according to the method described by Re et al. (1999) and adapted for small volumes by Sadat et al. (2011).

The $\mathrm{ABTS}^{+}$radical cation was produced by dissolving $7 \mathrm{mM}$ of cation $\mathrm{ABTS}^{+}$in $2.45 \mathrm{mM}$ potassium persulfate allowing the mixture to stand in the darkness for $15 \mathrm{~h}$ at room temperature before use. The $\mathrm{ABTS}^{+}{ }^{\bullet}$ radical cation reagent was then diluted with $5 \mathrm{mM}$ sodium phosphate buffer, $\mathrm{pH}$ 7.4 to reach an absorbance of ca. 0.7 at $740 \mathrm{~nm}$. The radical was stable for at least $1 \mathrm{~h}$ at $22^{\circ} \mathrm{C}$. A volume of $150 \mu \mathrm{L}$ of each sample $(\mathrm{CN}$ or $\mathrm{CNH}$ in $20 \%$ acetonitrile in water corresponding to different concentrations) was added to $150 \mu \mathrm{L}$ of the $\mathrm{ABTS}^{+}$. radical reagent, and incubated for $10 \mathrm{~min}$ at $30^{\circ} \mathrm{C}$. All the analyses were performed in triplicate. The absorbance was measured at $740 \mathrm{~nm}$ with an $\mathrm{MRX}^{\circledR}$ microplate reader. The radical scavenging activity of the tested samples, expressed as an inhibition percentage $(\%)$, was calculated with the equation:

$$
\text { Activity }(\%)=\left[1-\left(A_{r}-A_{b}\right) /\left(A_{i}-A_{b}\right)\right] \times 100
$$

Where $A_{i}$ is the absorbance of the initial ABTS $^{+}$. radical cation, $A_{r}$ is the absorbance of the remaining radical, and $A_{b}$ is the absorbance of the blank (in the case of phosphate buffer, $A_{b}=0.09$ ).

The $\mathrm{IC}_{50}$ value is defined as the concentration of sample which is able to transform $50 \%$ of $\mathrm{ABTS}^{+\cdot}$ to $\mathrm{ABTS}^{+}$, i.e. when the absorbance of the remaining radical $\left(A_{r}-A_{b}\right)$ was equal to that of the scavenged radical $\left(A_{i}-A_{r}\right)$. Thus, $\log I C_{50}$ corresponded to the $\mathrm{x}$-intercept of the curve $\log \left[\left(\mathrm{A}_{\mathrm{r}}-\mathrm{A}_{\mathrm{b}}\right) /\left(\mathrm{A}_{\mathrm{i}}-\mathrm{A}_{\mathrm{r}}\right)\right] v s$. $\log$ (Concentration of sample). 
The Trolox equivalent antioxidant capacity (TEAC) was calculated as described by Re et al. (1999).

\section{Statistical analysis}

Statistical analysis was performed using MS Excel software and results were presented as mean value \pm standard error of mean (SEM). The t-test (two-samples, assuming unequal variances) and $\mathrm{P}$ value $<0.05$ were used for statistical evaluation.

\section{Results and discussion}

Assessment of in vitro camel casein hydrolysis

Camel milk casein $(\mathrm{CN})$ and its hydrolysate generated by the successive actions of pepsin and pancreatin $(\mathrm{CNH})$ were analyzed by RP-HPLC (Figure 1).

In the chromatogram of intact camel casein, no peaks with important areas were eluted before 60 min. This confirms that the soluble nitrogen fraction of camel casein before digestion contained few small peptides. After hydrolysis, a number of large peaks were eluted between 5 and 70 min, whereas the casein's peak at 70 min disappeared in totality showing that the caseins were completely hydrolysed into peptides. The number of peptide bonds cleaved through the hydrolysis is often estimated by measuring the degree of hydrolysis (DH). The $\mathrm{DH}$ value reflects the content of amino groups liberated, the higher the $\mathrm{DH}$, the higher the content of released amino groups. The $\mathrm{DH}$ value of camel milk casein reached $19 \%$ after peptic and pancreatic digestion, which is lower than DH of bovine CN (25\%) obtained after $6 \mathrm{~h}$ of digestion by pancreatin, but higher than the DH of yak's (4\%) and ovine (4.5\%) milk casein hydrolyzed by microbial proteases for 4 h (Su et al., 2012; Jiang et al., 2007; Correa et al., 2011). The high $\mathrm{DH}$ of camel $\mathrm{CN}$ might be attributed to pepsin-specific target sites on camel milk $\mathrm{CN}\left(41,36,45\right.$ and 23 for $\alpha_{\mathrm{s} 1}-\mathrm{CN} ; \alpha_{\mathrm{s} 2}-\mathrm{CN} ; \beta-\mathrm{CN}$ and $\kappa-\mathrm{CN}$, respectively; Swiss-Prot. accession numbers: O97943,O97944,Q9TVD0, and P79139, respectively). Indeed, camel caseins were more readily digested with chymotrypsin than trypsin (S alami et al., 2008). Recently, Si Ahmed et al. (2013) reported that $\beta$-CN of camel milk is rapidly hydrolyzed by pepsin but it is more resistant to trypsin, chymotrypsin
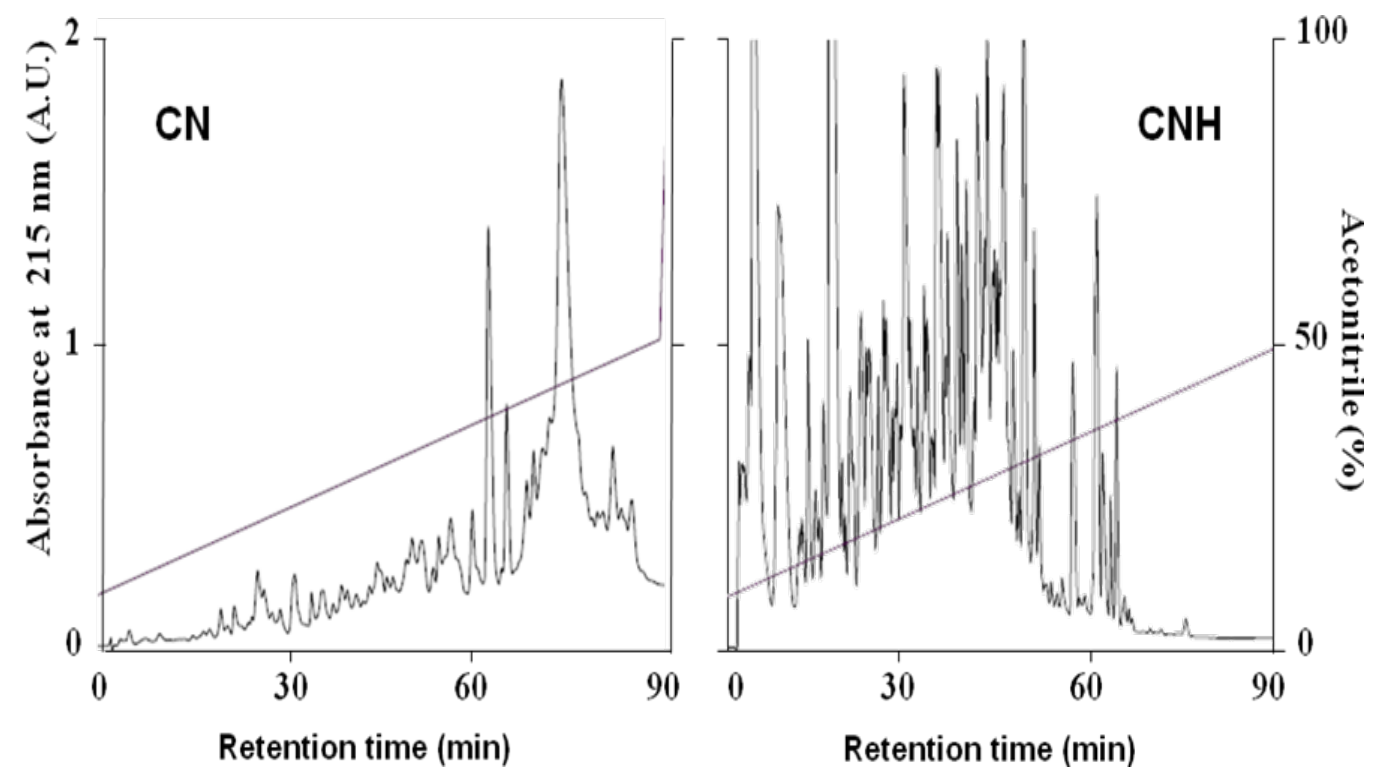

Figure 1. RP-HPLC chromatograms of camel milk casein $(\mathrm{CN})$ and its hydrolysate $(\mathrm{CNH})$ generated by successive actions of pepsin and pancreatin. See the Materials and Methods section for HPLC conditions. A.U.: Absorbance Unit 
and papain digestion than its counterpart which is purified from bovine milk.

\section{Free radical scavenging activity}

Antioxidant mechanisms of peptides include radical-scavenging (both hydrogen-donating capability and free radical quenching) activity, inhibition of lipid peroxidation, metal ion chelation, or a combination of these properties are well investigated. In this study, scavenging activity was determined using the radical cation $\mathrm{ABTS}^{+}$, which is reduced by concomitant conversion to a colorless product in the presence of antioxidants by hydrogen-donating or chain-breaking properties. Prior to the investigation of the radical scavenging-activity of camel casein and its hydrolysate, two strongly antioxidant molecules, gallic acid and Trolox, were used as positive controls. Figure 2 showed a linear concentration response curve in the range of $0-5$ and $0-10 \mu \mathrm{M}$ of gallic acid and Trolox, respectively. Gallic acid has a higher radical scavenging activity than that of Trolox with a Trolox Equivalent Antioxidant Capacity (TEAC) value of $3 \mu \mathrm{M}$ and an $\mathrm{IC}_{50}$ of $2.0 \mu \mathrm{M}$, the latter was similar to that reported by Sadat et al. (2011).

The radical scavenging activities of $\mathrm{CN}$ and $\mathrm{CNH}$ were investigated also by the determination of the $\mathrm{IC}_{50}$ and TEAC values and compared with those of camel milk protein (MP) determined in our previous study (Table 1). Thus, $\mathrm{CN}$ exhibited a higher free radical scavenging activity than the whole camel milk proteins (MP), with a 6 folds higher TEAC value and with $\mathrm{IC}_{50}$ values c.a. 2 fold lower than that of MP. After subsequent hydrolysis by pepsin and pancreatin, the $\mathrm{IC}_{50}$ value determined for the $\mathrm{CNH}$ hydrolysate was in the same order of magnitude than that of the protein fraction (the $\mathrm{IC}_{50}$ value of $\mathrm{CNH}$ was about 2 fold lower than that of the camel milk protein hydrolysate MPH). The TEAC value of $\mathrm{CNH}$ was 2 fold higher than that of $\mathrm{MPH}$, indicating that the $\mathrm{CNH}$ displayed stronger radical scavenging activities than MPH. The increase of free radical scavenging activity of camel milk proteins and of
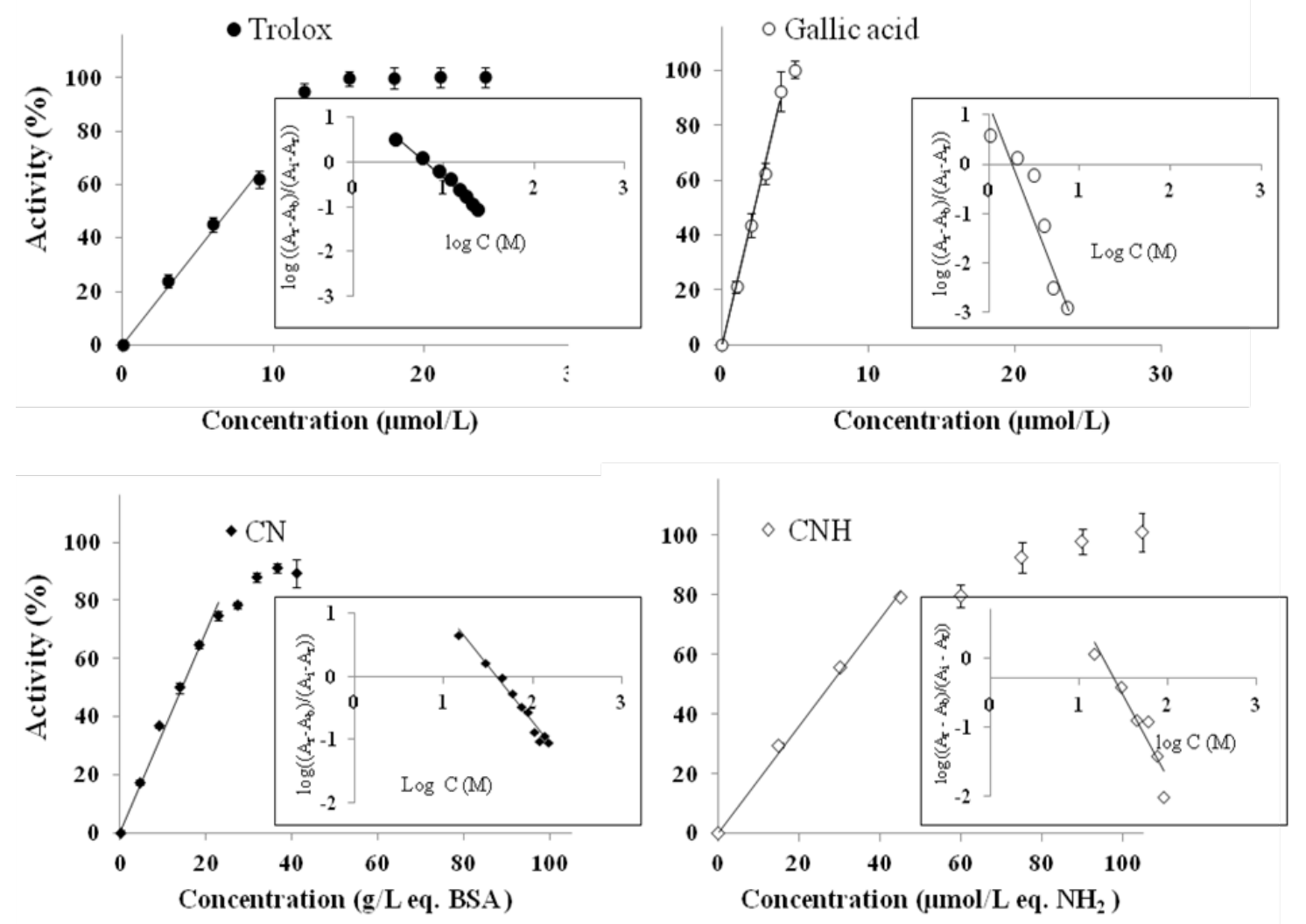

Figure 2. ABTS radical scavenging activity of Trolox, gallic acid, camel milk casein (CN), and its hydrolysate $(\mathrm{CNH})$ 
Table 1.TEAC and $\mathrm{IC}_{50}$ of gallic acid, camel casein $(\mathrm{CN})$, camel milk protein (MP), camel casein hydrolysate $(\mathrm{CNH})$ and camel milk proteins hydrolysate $(\mathrm{MPH})$

\begin{tabular}{ccc}
\hline Sample & TEAC \pm SEM & $\mathrm{IC}_{50} \pm \mathrm{SEM}$ \\
\hline Gallic acid & $\mu \mathrm{mol} \mathrm{TE} / \mathrm{mg}$ protein & $\mathrm{a}$ \\
$\mathrm{CN}$ & $3 \mu \mathrm{mol} / \mathrm{L}$ & $2 \mu \mathrm{mol} / \mathrm{L}$ \\
$\mathrm{MP}$ & $1.60 \pm 0.12$ & $12.03 \pm 2.17$ \\
& $0.26 \pm 0.03^{\mathrm{b}}$ & $24.7 \pm 0.27^{\mathrm{b}}$ \\
$\mathrm{CNH}$ & $\mu \mathrm{mol} \mathrm{TE} / \mu \mathrm{mol}$ eq. $\mathrm{NH}_{2}{ }^{\mathrm{a}}$ & $\mu \mathrm{mol} / \mathrm{L} \mathrm{eq.} \mathrm{NH}_{2}$ \\
$\mathrm{MPH}$ & $0.25 \pm 0.01$ & $24.70 \pm 2.98$ \\
\hline
\end{tabular}

${ }^{a}$ TE - a calculated Trolox equivalent expressed in $\mathrm{mg}^{-1}$ protein for undigested samples and $\mu \mathrm{mol}^{-1}$ eq. $\mathrm{NH}_{2}$ for the hydrolysates. The TEAC is the ratio of the slope of the plot of scavenging activity $v s$ concentration of the sample over the slope of the plot of Trolox;

${ }^{\mathrm{b}}$ Results from J rad et al. (2014)

casein after their hydrolysis suggested that antioxidative peptides were released and these peptides were mainly generated from the caseins rather than from the whey proteins.

It is now well-known that in bovine milk, $\beta-\mathrm{CN}$ produced radical scavenging peptides during gastrointestinal digestion or fermentation (Kansci et al., 2004). As camel milk casein fraction is rich in $\beta-\mathrm{CN}$ (65\% of total caseins), this component might be the best source of antioxidant peptides (Jrad et al., 2014). Camel $\beta-C N$ showed high antioxidant activity after hydrolysis with chymotrypsin (Salami et al., 2011). The camel $\beta-C N$ (Swiss-Prot accession number Q9TVD0) includes 8 residues of Phe, a highly antiradicalar aromatic amino acid, whereas bovine $\beta-\mathrm{CN}$ contains 5 Phe residues (Swiss-Prot accession number P02666) and might be one explanation of the potential antioxidant activity of the camel protein. Tsopmo et al. (2011) have reported that the presence of aromatic residues confers high free radical scavenging activity to synthetic peptides, the most efficient residue being Trp.

The antioxidant activity of peptides has been attributed to certain amino acid sequences (Suetsuna et al., 2000) as well as to the presence of peptide bonds present or structural conformation arrangement (Hernandez-Ledesma et al., 2007). The hydrophobicity of the peptide also appears to be an important factor for its antioxidant activity due to increased accessibility to hydrophobic targets (Chen et al., 1998). In fact, camel $\beta-C N$ hydropathy is -0.339 , which is the highest hydrophobicity among other camel caseins (www.expasy.org).
Thus, another factor must be taken into account to explain the radical scavenging activity of $\mathrm{CN}$ which is their polar domains that contain phosphorylated serine residues. Those phosphorylated $\mathrm{CN}$ and their caseinophosphopeptides (the so-called CPPs) exhibited antioxidant property towards direct free radical quenching activity (Kitts, 2005).

\section{Conclusion}

Camel milk has developed a high reputation as a healthy nutrition with most of its therapeutic value ascribed to its biological properties such as antioxidant activity. In this study, improvement of the free-radical scavenging activity of camel casein was unveiled after in vitro hydrolysis by pepsin and pancreatin to simulate the gastro-intestinal digestion. These preliminary results showed the generation of antioxidative peptides from camel caseins. Therefore, further studies are necessary to identify the antioxidant peptides and to investigate the possibility of the gastro-intestinal system to generate camel milk antioxidant peptides in vivo.

\section{Acknowledgments}

The authors thank Dr Awatef Boubakri (The Higher Institute of Applied Studies in Humanities at Medenine, University of Gabes, Tunisia) for his kind help with English. 


\section{Antioksidativnost kazeina devinog mlijeka prije $i$ nakon in vitro simulirane enzimske razgradnje}

$\mathrm{U}$ radu je istražen utjecaj in vitro hidrolize kazeina devinog mlijeka sa pepsinom i pankreatinom na koncentraciju slobodnih radikala $i$ antioksidativnu aktivnost s ciljem procjenjivanja utjecaja gastrointestinalne razgradnje. Hidroliza kazeina praćena je sa RP-HPLC (tekućinska kromatografija visoke djelotvornosti na obrnutim fazama). Antioksidativna aktivnost je praćena sa 2,2'-azino-bis-(3-ethylbensothiazoline-6-sulfonic acid) (ABTS) metodom. Ekvivalent troloks antioksidativnog kapaciteta (TEAC) devinog kazeina iznosio je 1.6 $\pm 0.12 \mu \mathrm{mol}$ $\mathrm{TE} / \mathrm{mg}$ proteina, dok je TEAC hidrolizata iznosio $0.25 \mu \mathrm{mol} \mathrm{TE} / \mu \mathrm{mol}$ eq. $\mathrm{NH}_{2}$. Nakon digestije, utvrđena antioksidativna aktivnost kazeinskih peptida bila je učinkovitija od literaturnih navoda za hidrolizate devinog mlijeka, kolostruma i sirutkinih proteina.

\section{Ključne riječi: devin kazein, protein enzimska probava, radikalna aktivnost čišćenja, antioksidans}

\section{References}

1. Bradford, M.M. (1976): A rapid and sensitive method for the quantitation of microgram quantities of protein utilizing the principle of proteindye binding. Analytical Biochemistry 72, 249-254. doi: dx.doi.org/10.1016/0003-2697(76)90527-3

2. Chen, H.M., Muramoto, K., Yamauchi, F., Fujimoto, K., Nokihara, K. (1998): Antioxidative properties of histidine-containing peptides designed from peptide fragments found in the digests of a soybean protein. Journal of Agriculture and Food Chemistry 46, 49-53. doi: dx.doi.org/10.1021/jf970649w

3. Corrêa, A.P.F., Daroit, D.J., Coelho, J., Meira, S.M.M., Lopez, F.C., Segalin, J., Risso, P.H., Brandelli, A. (2011): Antioxidant, antihypertensive and antimicrobial properties of ovine milk caseinate hydrolyzed with a microbial protease. Journal of Science and Food Agriculture 91, 2247-2254.

4. Dávalos, A., Miguel, M., Bartolomé, B., Lopez-Fandino, R. (2004): Antioxidant activity of peptides derived from egg white proteins by enzymatica hydrolysis. Journal of Food Protection 67, 1939-1944.

5. Frister, H., Meisel, H., Schlimme, E. (1988): OPA method modified by use of N, N-dimethyl-2 mercaptoethylammonium chloride as thiol component. Fresenius Journal of Analytical Chemistry 330, 631-633. doi: dx.doi.org/10.1007/BF00473782
6. Hernandez-Ledesma, B., Amigo, L., Recio, I., Bartolome, B. (2007): ACE-inhibitory and radical-scavenging activity of peptides derived from $\beta$-lactoglobulin $f$ (19-25). Interactions with ascorbic acid. Journal of Agriculture and Food Chemistry 55, 3392-3397. doi: dx.doi.org/10.1021/jf063427j

7. Jiang, J., Chen, S., Ren, F., Luo, Z., Zeng, S.S. (2007): Yak milk casein as a functional ingredient: preparation and identification of angiotensin-I-converting enzyme inhibitory peptides. Journal of Dairy Research 74, 18-25. doi: dx.doi.org/10.1017/S0022029906002056

8. Jrad, Z., El Hatmi, H., Adt, I., Girardet, J.-M., CakirKiefer, C., Jardin, J., Degraeve, P., Khorchani, T., Oulahal, N. (2014): Effect of digestive enzymes on antimicrobial, radical scavenging and angiotensin I-converting enzyme inhibitory activities of camel colostrum and milk proteins. Dairy Science and Technology 94, 205-224. doi: dx.doi.org/10.1007/s13594-013-0154-1

9. Kansci, G., Genot, C., Meynier, A., Gaucheron, F., Chobert, J.-M. (2004): $\beta$-Caseinophosphopeptide (f1-25) confers on $\beta$-casein tryptic hydrolysate an antioxidant activity during iron/ascorbate-induced oxidation of liposomes. Lait 84, 449-462. doi: dx.doi.org/10.1051/lait:2004019

10. Kappeler, S. (1998): Compositional and structural analysis of camel milk proteins with emphasis on protective proteins. Ph.D. Thesis, Swiss Federal Institute of Thechnology, Zurich.

11. Kaur, C., Kapoor, H.C. (2001): Antioxidant in fruits and vegetables-themillennium's health. International Journal of Food Science and Technology 36, 703-725. doi: dx.doi.org/10.1046/j.1365-2621.2001.00513.x

12. Kitts, D.D. (2005): Antioxidant properties of casein-phosphopeptides. Trends in Food Science and Technology 16, 549-554. doi: dx.doi.org/10.1016/j.tifs.2005.08.009

13. Parrot, S., Degraeve, P., Curia, C., Martial-Gros, A. (2003): In vitro study on digestion of peptides in Emmental cheese: Analytical evaluation and influence on angiotensin I converting enzyme inhibitory peptides. Nahrung/Food 47, 87-94. doi: dx.doi.org/10.1002/food.200390032

14. Pihlanto, A. (2006): Antioxidative peptides derived from milk proteins. International Dairy Journal 16, 1306-1314. doi: dx.doi.org/10.1016/j.idairyj.2006.06.005

15. Quan, S., Tsuda, H., Miyamoto, T. (2008): Angiotensin-I-converting enzyme inhibitory peptide in skim milk fermented with Lactobacillus helveticus 130B4 from camel milk in Inner Mongolia, China. Journal of Science and Food Agriculture 88, 2688-2692. doi: dx.doi.org/10.1002/jsfa.3394

16. Re, R., Pelligrini, N., Proteggente, A., Pannala, A., Yang, M., Price-Evans, C. (1999): Antioxidant activity applying an improved ABTS radical cationdecolourisation assay. Free Radical Biology \& Medicine 26, 1231-1237. doi: dx.doi.org/10.1016/S0891-5849(98)00315-3 
17. Ren, J., Zhao, M., Shi, J., Wang, J., Jiang, Y., Cui, C., Kakuda, Y., Xue, S.J. (2008): Purification and identification of antioxidant peptides from grass carp muscle hydrolysates by consecutive chromatography and electrospray ionization-mass spectrometry. Food Chemistry 108, 727-736. doi: dx.doi.org/10.1016/j.foodchem.2007.11.010

18. Sadat, L., Cakir-Kiefer, C., N'Negue, M.-A., Gaillard, J.-L., Girardet, J.-M.,Miclo, L. (2011): Isolation and identification of antioxidant peptides from bovine $\alpha$-lactalbumin. International Dairy Journal 21, 214-221. doi: dx.doi.org/10.1016/j.idairyj.2010.11.011

19. Saiga, A., Tanabe, S., Nishimura, T. (2003): Antioxidant activity of peptides obtained from porcine myofibrillar proteins by protease treatment. Journal of Agriculture and Food Chemistry 51, 3661-3667. doi: dx.doi.org/10.1021/jf021156g

20. Sakanaka, S., Tachibana, Y., Ishihara, N., Raj Juneja, L. (2004): Antioxidant activity of egg-yolk protein hydrolysates in a linoleic acid oxidation system. Food Chemistry 86, 99-103. doi: dx.doi.org/10.1016/j.foodchem.2003.08.014

21. Salami, M., Yousefi, R., Ehsani, M.R., Dalgalarrondo, M., Chobert, J.-M., Haertlé, T., Razavi, S.H., Saboury, A.A., Niasari-Naslaji, A., Moosavi-Movahedi, A.A. (2008): Kinetic characterization of hydrolysis of camel and bovine milk proteins by pancreatic enzymes. International Dairy Journal 18, 1097-1102.

22. Salami, M., Moosavi-Movahedi, A.A., Moosavi-Movahedi, F., Ehsani, M.R., Yousefi, R., Fahadi, M., Niasari-Naslaji, A., Saboury, A.A., Chobert, J.-M.,Haertlé, T. (2011): Biological activity of camel milk casein following enzymatic digestion. Journal of Dairy Research 78, 471-487. doi: dx.doi.org/10.1017/S0022029911000628

23. Sboui, A., Khorchani, T., Djegham, M., Agrebi, A., El Hatmi, H., Belhaj, O. (2010): Antidiabetic effect of camel milk in alloxan-induced diabetic dogs: a doseresponse experiment. Journal of Animal Physiology and Animal Nutrition 9, 540-546.
24. Si Ahmed, Z.S., Almi, D., Senoussi, C., Boudjenah, S.H., Mati, A. (2013): Separation and characterization of major milk proteins from Algerian Dromedary (Camelusdromedarius). Emirate Journal of Food Agriculture 25, 283-290.

25. Spellman, D., McEvoy, E., O'Cuinn, G., FitzGerald, R.J. (2003): Proteinase and exopeptidase hydrolysis of whey protein: comparison of the TNBS, OPA and $\mathrm{pH}$ stat methods for quantification of degree of hydrolysis. International Dairy Journal 13, 447-453. doi: dx.doi.org/10.1016/S0958-6946(03)00053-0

26. Su, R., Liang, M., Qi, W., Liu, R., Yuan, S., He, Z. (2012): Pancreatic hydrolysis of bovine casein: Peptide release and time-dependent reaction behavior. Food Chemistry 133, 851-858. doi: dx.doi.org/10.1016/j.foodchem.2012.01.103

27. Suetsuna, K., Ukeda, H., Ochi, H. (2000): Isolation and characterisation of free radical scavenging activities peptides derived from casein. Journal of Nutritional Biochemistry 11, 128-131. doi: dx.doi.org/10.1016/S0955-2863(99)00083-2

28. Tsopmo, A., Romanowski, A., Banda, L., Lavoie, J.C., Jenssen, H., Friel, J.K. (2011): Novel antioxidative peptides from enzymatic digestion of human milk. Food Chemistry 126, 1138-1143. doi: dx.doi.org/10.1016/j.foodchem.2010.11.146

29. Zhou, D., Zhu, B., Qiao, L., Wu, H., Li, D., Yang, J., Murata, Y. (2012): In vitro antioxidant activity of enzymatic hydrolysates prepared from abalone (HaliotisdiscushannaiIno) viscera. Food Bioproducts Process 90, 148-154. doi: dx.doi.org/10.1016/j.fbp.2011.02.002 